\title{
2006-570: APPLYING ENGINEERING ECONOMIC ANALYSIS TO CONTEMPORARY PROBLEMS WITH GLOBAL AND SOCIETAL IMPLICATIONS
}

\section{Karen Bursic, University of Pittsburgh}

Karen M. Bursic is an Assistant Professor in Industrial Engineering at the University of Pittsburgh. She received her B.S., M.S., and Ph.D. degrees in Industrial Engineering from the University of Pittsburgh. She specializes in teaching courses in engineering economic analysis, probability and statistics, and engineering computing. Prior to joining the department she worked as a Senior Consultant for Ernst and Young and as an Industrial Engineer for General Motors Corporation. She has also taught in the Katz Graduate School of Business (at the University of Pittsburgh) and at The Pennsylvania State University. Dr. Bursic has done research and published work in the areas Engineering and Project Management and Engineering Education. She is a member of IIE and ASEE and is a registered Professional Engineer in the state of Pennsylvania. 


\section{Applying Engineering Economic Analysis to Contemporary Problems with Global and Societal Implications}

\section{Abstract}

This paper describes the use of contemporary issues to teach students to solve problems in a global and societal context in an introductory engineering economic analysis course at the University of Pittsburgh. The goals of the project are to increase student understanding and awareness of contemporary decision making in engineering and ensure that students are able to apply the economic concepts and techniques being taught in the classroom to these decisions. A form of the problem-based learning methodology is applied here. This project is also aimed at meeting the requirements of the ABET outcomes $h$. and $j$. The paper describes this effort and reviews student self-report surveys regarding whether completing the course project contributed to their understanding of and ability to make decisions and solve contemporary problems. The results show the benefits of this approach and the need to continue to refine such efforts in the classroom.

\section{Introduction}

The ability to complete an economic analysis is a core competency for any engineer employed in a decision-making role. Engineers must be able to apply the body of knowledge that is taught under the heading of "engineering economic analysis" in contemporary problem solving situations. As many engineering education researchers have pointed out, if we are to be successful in meeting ABET criteria and improving undergraduate engineering education, we must begin to teach students to be "problem solvers". 5, 6,7 Problem-based learning is a methodology in which complex open-ended problems requiring students to apply the course knowledge and skills are introduced. These problems are typically posed before the knowledge and skills are actually taught in order to motivate learning. Typically the problems are worked on in teams. The application of problem-based learning in engineering education is not new and has been proven to be successful in many programs. ${ }^{1,2,4,8,10,12}$ With the assignment described in this paper, we are attempting a form of problem-based learning by assigning a project during the first week of class. This project requires the application of the techniques and methodologies taught throughout the semester and is completed in small groups.

In the School of Engineering at the University of Pittsburgh, our three-credit introductory economic analysis course (IE 1040) is a service course taught to over 200 engineering students per year from all disciplines within the school. The course has traditionally required the completion of a project. In the past, students were permitted to select their own project ideas; however this often led to students solving trivial, unrealistic, or non-contemporary problems. In addition, little connection was made between the course learning objectives and the ongoing projects. Beginning in the 2005-2006 academic year, students enrolled in the course are required to research and complete an economic analysis of an assigned problem. Students chose from one of two contemporary problems that may be encountered in industrial organizations. With the 
limited choice of problems, the instructor is better able to show connections between course material and applications to the project.

The goals of the project are to increase student understanding and awareness of contemporary decision making in engineering and ensure that students are able to apply the economic concepts and techniques being taught in the classroom. This project is just one part of our efforts to meet the requirements of $\mathrm{ABET}$ in that it directly addresses two required outcomes. "Engineering programs must demonstrate that their students attain: ... (h) the broad education necessary to understand the impact of engineering solutions in a global, economic, environmental, and societal context ... (j) a knowledge of contemporary issues."3 Ideally, we would like to be able to require a separate course that directly addresses contemporary problem-solving in a global society. Many of the University's programs have offerings that might be suitable. However, while the undergraduate faculty is considering this option, with an already cramped curriculum it is a difficult decision. In addition, presenting students with contemporary engineering problems that require students to put them in a global, economic, environmental, and/or societal context may prove to be a better approach. In this manner students are able to clearly see the relevance of these issues to their own field of interest. This problem-based learning approach can also be used to address the department's goal of an integrated curriculum. ${ }^{11}$

\section{Method}

In both the fall of 2005 and spring of 2006, students were required to choose one of the following two contemporary problems:

1) Implementing RFID (Radio Frequency Identification) technology - In this case, students were to assume the role of Vice President of Operations or owner of a business that supplies products to a retailer such as Wal-Mart. Their company is being asked to comply with standards that force them to include RFID on all of their products.

2) Outsourcing production operations overseas - In this case, students were to assume the role of Vice President of Operations or owner of a large U.S. based manufacturing company. The company must decide whether to outsource some or all of their labor intensive operations to China.

In both cases students were to do a complete economic analysis of the situation using the techniques taught throughout the semester. Students were asked to address questions such as: What are the costs and economic benefits? What are the costs of not implementing the project? Do the benefits outweigh the costs? Is this an economically profitable project or decision? In addition, students were specifically asked to consider the societal implications of implementing the RFID technology or outsourcing operations and determine what role these implications might play in the decision. No particular economic analysis techniques (present worth analysis, rate of return analysis, benefit/cost ratios, etc.) were required. Instead students were encouraged to determine on their own what methods and techniques covered during the semester might be applied to their case. Students worked in groups of three or four. The scenarios described above were purposely left open-ended and the project topics were not further defined by the instructor so as to allow for some creativity and require the students to do some research to find the data 
needed for a complete economic analysis. Throughout the semester, the instructor would point out when techniques and methods being taught might be applied to the project.

The students were required to submit a short mid-semester report to ensure that they had begun researching and planning their approach to the analysis. Final project reports were due the last week of class. Students were given a general outline to be used in writing their reports (see Figure 1). The projects were graded using a pre-defined grading rubric based on this outline and using a total of 100 points.

Once the projects had been submitted, students were asked to complete a short survey to evaluate the effectiveness of the project as a learning tool. The survey was aimed at determining whether students felt that the project increased their understanding and awareness of global, societal, and contemporary problems and the application of the course material.

The report should include the following:

The Situation and Decision:

- Description of the situation

- Specific economic decision(s) involved

- Societal implications of the decision

- Description of available data

- Assumptions you have made

The Solution:

- Description of the economic analysis techniques that are applicable to the problem or situation and calculations associated with those techniques

- What decision you would make

Note that since you may not have complete information about the situation, you may use reasonable estimates of various figures in your analysis.

Figure 1: Project Report Formatting

The survey identified students by course section, discipline, and which project they worked on. The following four questions were asked:

1. The IE 1040 Semester Project was useful in teaching me to apply the concepts learned in the course to a real world problem

2. The Project increased my knowledge of contemporary problems and issues in engineering

3. The Project increased my awareness of the societal implications of engineering decisionmaking 
4. The Project increased my awareness of the global implications of engineering decisionmaking

A five point Likert scale ( 1 - Hardly at all; 2 - To a small degree; 3 - To a moderate degree; 4 To a considerable degree; and 5 - To a high degree) was used.

Results

Only the results from the fall semester (2005) are available at the time of this writing. Two sections of the course were offered. Section 1 consisted of primarily Civil Engineering (CE) students with a final enrollment of 74 students. The survey data for Section 1 consists of $58 \mathrm{CE}$ students and 15 from other departments in the School of Engineering. Section 2 was a dedicated Industrial Engineering (IE) student section with a final enrollment of 63 students. The survey data for Section 2 consists of 43 IE students and 9 from other departments. Section 1 met once a week for $2 \frac{1}{2}$ hours per session while Section 2 met twice a week for 1 hour and 15 minutes per session.

The average grade on the project was 84.5 with a standard deviation of 4.1 in Section 1 and 84.9 in Section 2 with a standard deviation of 3.7. There was no statistical difference in the grading for the two sections. In the fall of 2004 (when students selected their own projects and no requirements regarding global or societal implications were given) the Section 1 average was higher at 88.86 with a standard deviation of 4.43 and a sample size of 43 (p-value $=0$ when compared to the same section in the fall 2005 semester). The section 2 average was also higher in fall 2004 than in fall 2005 (average of 88.6, standard deviation of 3.74, sample size of 42 and $\mathrm{p}$-value $=0$ ). It appears that the additional requirements to address the global and societal issues did affect overall student performance on the projects.

Overall the students did well on the project; however a closer look at the grading does reveal that the majority of points were lost for a weak analysis of the non-economic issues such as the global and societal impacts of the two decisions situations. Thus while students did an admirable job on the economic analysis techniques (including gathering appropriate data, identifying alternatives, developing potential outcomes and differences in cash flows, applying present worth analysis, rate of return, or $\mathrm{B} / \mathrm{C}$ ratios, and making a decision), they did not do a good job when it came to considering the non-economic impacts of their decisions. Such issues as public concern over privacy (in the RFID case) and poor public relations for a company as a result of job cuts (in the outsourcing case) were mentioned, but little effort was made to estimate the actual economic effects of these issues and how they might impact the final decision. Although it is not clear why this is true, the most likely conclusion is that the students simply do not know how to determine the economic consequences of qualitative benefits and disbenefits.

Traditionally, when we teach cost estimation the focus is on those expenses and revenues that can be easily put in quantitative terms.

The results of the self-report survey (Table 1) do show that while they may not have done a superior job of analyzing and describing the global and societal implications, the students did believe that the project increased their knowledge or awareness of them. Most of the average scores from the survey are well above 3 on the 5 point scale. 
Overall the outsourcing project scored better when it came to applying the course material, increasing student knowledge of contemporary problems, and increasing student awareness of the societal and global impacts of engineering decision making. There is a statistical difference ( $\mathrm{p}$-value $=.04$ ) between the two projects (outsourcing verses RFID) on the response to question 4 (awareness of global implications). This result is not unexpected since the RFID project could easily be analyzed without considering global implications while the outsourcing project, by definition, requires this consideration.

There was also a statistical differences in this data between Section 1 and Section 2 for the RFID project on the questions of knowledge of contemporary issues ( $p$-value $=.002)$ and the question of awareness of societal implications ( $\mathrm{p}$-value $=.033$ ). More students in Section 2 felt that the project increased their understanding of the issues. One explanation available for this difference is the difference in the way the two sections are taught. There was less time for the instructor to emphasize these issues in Section 1 due to the University calendar. The difference may also be due to the level of importance that is placed on the course by IE students versus CE students. Although the course is required for both groups, it is seen as a core course for the IE students.

\begin{tabular}{|l|c|c|c|c|c|}
\hline & & \multicolumn{4}{|c|}{ Question } \\
\hline & $\begin{array}{c}\text { Sample } \\
\text { Size }\end{array}$ & $\begin{array}{c}\mathbf{1 :} \\
\text { Application }\end{array}$ & $\begin{array}{c}\mathbf{2 :} \\
\text { Contemp. }\end{array}$ & $\begin{array}{c}\mathbf{3 :} \\
\text { Societal }\end{array}$ & $\begin{array}{c}\mathbf{4 :} \\
\text { Global }\end{array}$ \\
\hline Section 1 Outsourcing Averages & 24 & 3.50 & 3.33 & 3.54 & 3.42 \\
\hline Section 1 RFID Averages & 49 & 3.41 & 3.29 & 3.35 & 3.06 \\
\hline Section 2 Outsourcing Averages & 28 & 3.93 & 3.68 & 3.71 & 3.64 \\
\hline Section 2 RFID Averages & 24 & 3.92 & 4.00 & 3.83 & 3.33 \\
\hline Outsourcing Averages & $\mathbf{5 2}$ & $\mathbf{3 . 7 3}$ & $\mathbf{3 . 5 2}$ & $\mathbf{3 . 6 3}$ & $\mathbf{3 . 5 4}$ \\
\hline RFID Averages & $\mathbf{7 3}$ & $\mathbf{3 . 5 8}$ & $\mathbf{3 . 5 2}$ & $\mathbf{3 . 5 1}$ & $\mathbf{3 . 1 5}$ \\
\hline Overall Averages & $\mathbf{1 2 5}$ & $\mathbf{3 . 6 4}$ & $\mathbf{3 . 5 2}$ & $\mathbf{3 . 5 6}$ & $\mathbf{3 . 3 1}$ \\
\hline
\end{tabular}

Table 1: Results of self-report survey

\section{Conclusions and Future Work}

Problem-based learning is an ideal teaching methodology that can be used to address the ABET outcomes discussed earlier and was effective to some degree in this case. To increase the effectiveness of the approach, additional classroom time must be spent on integration of concepts so that students are better able to address the global and societal issues in their projects. If time and resources permit, the syllabus should allow for a complete lecture or two on topics such as business decision-making in a global society as well as the social impacts of those decisions. One approach might be to bring in a guest speaker with expertise in these areas that could help students identify the issues and determine how they play a role in engineering decision making. In addition, the instructor must continue to search for additional contemporary problems in which economic analysis can be applied and for which there are societal and global implications. This requires a concerted effort on the part of the instructor during course preparation.

While it is recognized that the project described here was limited to one school and one course, it is also believed that the idea presented clearly has applications at other schools and in other 
courses. Any introductory course aimed at teaching basic engineering techniques for decision making can include comprehensive problem solving that requires students to apply the engineering tools as well as consider other global and societal impacts of their decisions. One such example is an introductory probability and statistics course. While a straightforward statistical analysis might show that that the use of alternative fuels statistically increases gas mileage, a decision to develop these fuels cannot be made without considering cost (economic impacts) or environmental impacts.

We will continue to refine the engineering economic analysis course project requirements while also considering how to introduce similar content in other courses. In the end, as with any successful undergraduate engineering program, we would ideally like to produce graduates that are able to step into industry not only with an ability to use modern engineering tools but with excellent problem solving skills.

Bibliography

[1] Bower, K.C., Mays, T.W. and Miller, C.M. (2004), "Small group, Self-directed Problem Based Learning Development in a Traditional Engineering Program," Proceedings - Frontiers in Education Conference, 34th Annual Frontiers in Education: Expanding Educational Opportunities through Partnerships and Distance Learning - Conference Proceedings, FIE, 3, S1B-16-S1B-21.

[2] Cline, M. and Powers, G.J. (1997), "Problem Based Learning via Open Ended Projects in Carnegie Mellon University's Chemical Engineering Undergraduate Laboratory," Frontiers in Education Conference, 1997, 27th Annual Conference. 'Teaching and Learning in an Era of Change'. Proceedings, 350-354.

[3] Criteria For Accrediting Engineering Programs (Effective for Evaluations During the 2005-2006 Accreditation Cycle); Engineering Accreditation Commission; ABET, Inc. Baltimore, MD November 1, 2004.

[4] De Camargo Ribeiro, L.R. and Mizukami, M.G.N. (2005), "Student Assessment of a Problem-Based Learning Experiment in Civil Engineering Education," Journal of Professional Issues in Engineering Education and Practice, 131(1), 13-18.

[5] Dym, C.L., Agogino, A.M., Eris, O., Frey, D. D., and Leifer, L.J. (2005). “Engineering Design Thinking, Teaching, and Learning," Journal of Engineering Education, 94(1), 103-120.

[6] Felder, R. and Brent, R. (2003). "Designing and Teaching Courses to Satisfy the ABET Engineering Criteria," Journal of Engineering Education, 92(1), 7-25.

[7] Fink, L.D., Ambrose, S., and Wheeler, Daniel (2005). "Becoming a Professional Engineering Educator: A New Role for a New Era," Journal of Engineering Education, 94(1), 185-194.

[8] Havener, A.G. and Barlow, D.N. (2002), "Project Falcon Base: A Freshman Introduction to Engineering Using Problem Based Learning," ASEE Annual Conference Proceedings, 2002 ASEE Annual Conference and Exposition, 8341-8354.

[9] McMaster University, http://chemeng.mcmaster.ca/pbl/pbl.htm, Accessed January 5, 2006.

[10] Nasr, K.J. and Ramadan, B. (2005), "Implementation of Problem-Based Learning into Engineering Thermodynamics," ASEE Annual Conference and Exposition, Conference Proceedings, 2005 ASEE Annual Conference and Exposition, Conference Proceedings, 7619-7635. 
[11]Norman, B. A., Besterfield-Sacre, M., Bidanda, B., Needy, K. L., and Rajgopal, J. (2004), “A Conceptual Model for Integrating and Synthesizing the Industrial Engineering Curriculum," 2004 American Society for Engineering Education Annual Conference Proceedings, Salt Lake City, UT.

[12] Striegel, A. and Rover, D.T. (2002), "Problem-Based Learning in an Introductory Computer-Engineering Course," Proceedings - Frontiers in Education Conference, 2, F1G/7-F1G/12. 